\author{
Adam Sitarek \\ Uniwersytet Łódzki, Centrum Badań Żydowskich \\ https://orcid.org/0000-0002-3958-7262 \\ adam.sitarek@uni.lodz.pl
}

\title{
Danuta Dąbrowska - pionierka badań nad łódzkim gettem
}

\begin{abstract}
Streszczenie
Danuta Dąbrowska była pierwszą badaczką historii łódzkiego getta. Urodzona w Niemczech, przeżyła okupację w falenickim getcie, a następnie ukrywając się po tzw. aryjskiej stronie w Warszawie. Po wyzwoleniu podjęła studia humanistyczne i pracę w Żydowskim Instytucie Historycznym, gdzie w latach sześćdziesiątych przygotowała kilka artykułów naukowych poświęconych dziejom łódzkiego getta. Jednocześnie zaangażowała się w prace nad wydaniem Kroniki getta łódzkiego, które przerwano na skutek kampanii antysemickiej w Marcu 1968. W tym czasie Dąbrowska wyjechała z Polski i zamieszkała w Izraelu, gdzie kontynuowała pracę naukową w Instytucie Yad Vashem w Jerozolimie.
\end{abstract}

\section{Słowa kluczowe}

Danuta Dąbrowska, getto łódzkie, Żydowski Instytut Historyczny, historia historiografii, biografistyka

\begin{abstract}
Danuta Dąbrowska was the first to research the history of the Łódź ghetto. Born in Germany, she survived the occupation in the Falenica ghetto, and was subsequently hiding on the socalled "Aryan side" in Warsaw. After liberation she took up arts studies and worked at the Jewish Historical Institute, where in the 1960s she prepared several scientific articles on the history of the Łódź ghetto. At the same time, she became involved in work on the Chronicle of the Łódź Ghetto, which was interrupted by the anti-Semitic campaign of March'68. It was then that Dąbrowska left Poland and settled in Israel, where she continued her scientific work at the Yad Vashem Institute in Jerusalem.
\end{abstract}

\section{Key words}

Danuta Dąbrowska, Łódź ghetto, Jewish Historical Institute, history of historiography, biographical studies

Nie ma książki poświęconej historii łódzkiego getta, która nie odwoływałaby się w bibliografii do prac Danuty Dąbrowskiej. Choć w karierze naukowej napisała ich stosunkowo niewiele, waga poruszanych tematów, nowatorskie ujęcie problemów oraz niezwykle wysoki poziom warsztatu naukowego sprawiają, że 
weszła na stałe do grona najważniejszych badaczy tego tematu. Badania te podjęła jako jedna z pierwszych, co w pełni usprawiedliwia nazywanie ją pionierką badań nad dziejami łódzkiej „dzielnicy zamkniętej”, a potwierdzeniem mogą być prace poświęcone m.in. administracji żydowskiej getta, rozpoczęte przez nią w 1965 r. ${ }^{1}$, które doczekały się kontynuatorów 50 lat później². Sama historyczka, osoba niezwykle skromna i życzliwa, nie zgadzała się z taką oceną, a wszelkie wyrazy uznania traktowała jako „mocno przesadzone”3.

Danuta Dąbrowska, zwana przez przyjaciół Kubusią, urodziła się 12 stycznia 1927 r. w Berlinie jako córka Henryka Blidsztejna i Idalii z domu Jurzdyckiej Rodzice znaleźli się w Republice Weimarskiej w latach dwudziestych, gdy jako młodzi lekarze przybyli na praktyki. Jej rodowe nazwisko brzmiało Jakoba Fryda Blidsztejn, zmieniła je w 1942 r., gdy ukrywała się z matką po tzw. aryjskiej stronie $^{5}$. Do 1933 r. mieszkała w Berlinie pod opieką ciotki, po czym wróciła do Polski do rodziców ${ }^{6}$, co mogło być powiązane z dojściem do władzy Adolfa Hitlera i coraz agresywniejszą nagonką antyżydowską. Osiedliła się z rodzicami w Sarnakach w powiecie siedleckim, gdzie rodzice odbywali praktykę lekarską (matka jako dentystka), ale już w kolejnym roku wraz z matką, po rozwodzie rodziców, opuściła miejscowość i wyjechała do Warszawy, ojciec zaś udał się do Wilejki. W stolicy zamieszkała z matką i jej siostrą na Żoliborzu na I Kolonii Warszawskiej Spółdzielni Mieszkaniowej. Jeszcze przed wybuchem wojny rozpoczęła naukę w gimnazjum Robotniczego Towarzystwa Przyjaciół Dzieci ${ }^{7}$.

Gdy wybuchła wojna, razem z matką zostały zmuszone do przeniesienia się na teren tworzonego getta. Jednak jeszcze w 1940 r. z inicjatywy Idalii przeprowadziły się do Falenicy, gdzie również tworzono „dzielnicę zamkniętą”. Tam przebywały niemal do jego likwidacji. Matka Jakoby przygotowywała się do przejścia na aryjską stronę - $\mathrm{w}$ tym celu pozyskała dokumenty na przybrane nazwiska: Danuta Dąbrowska oraz Seweryna Michalska. Jeszcze przed wyjściem $\mathrm{z}$ getta Jakoba, korzystając z fałszywej tożsamości, kontynuowała naukę w ra-

${ }^{1}$ Administracja żydowska $w$ Łodzi i jej agendy w okresie od poczq̨tku okupacji do zamknięcia getta (8 IX 1939 - 30 IV 1940), „Biuletyn ŻIH” 1963, nr 1/2 (45/46), s. 110-137.

${ }^{2}$ Adam Sitarek, „Otoczone drutem państwo”. Struktura i funkcjonowanie administracji żydowskiej getta łódzkiego, Łódź: IPN, 2016.

${ }^{3}$ Zbiory Centrum Badań Żydowskich UŁ, List Danuty Dąbrowskiej do Ewy Wiatr, 16 VIII $2009 \mathrm{r}$.

${ }^{4}$ Archiwum Instytutu Pamięci Narodowej (dalej AIPN), 1268/20326, t. 2, Odpis skrócony aktu urodzenia, k. 1.

${ }^{5}$ W Archiwum Uniwersytetu Warszawskiego (dalej AUW) znajduje się odpis decyzji potwierdzającej zmianę nazwiska na Dąbrowska Danuta Bronisława (AUW, Akta studenta Dąbrowska Danuta, Odpis aktu zmiany nazwiska, b.p.).

${ }^{6}$ Archiwum Żydowskiego Instytutu Historycznego (dalej AŻIH), Akta personalne, t. 6, Dąbrowska Danuta - Życiorys, k. 32.

${ }^{7}$ Jakoba Blidsztejn (Danuta Dąbrowska) - Ocalona, https://sprawiedliwi.org.pl/pl/historie-pomocy/wasze-opowiesci/jakoba-blidsztejn-danuta-dabrowska-ocalona (dostęp 2 X 2020 r.). 
mach tajnych kompletów organizowanych przez RTPD. Opowiadała po wojnie, że w czasie jednego z wyjazdów na zajęcia została zatrzymana na Dworcu Wschodnim przez policjanta granatowego. Nie potrafiła wytłumaczyć, dlaczego zdradziła policjantowi prawdziwe imię i nazwisko oraz adres w getcie. Niebawem we wskazanym miejscu pojawił się szantażysta z policji granatowej w towarzystwie jeszcze jednego mężczyzny. Zażądali od zaskoczonej matki podania źródła pochodzenia fałszywych dokumentów. Jak wspominała Danuta, matka z pomocą wódki i kiełbasy oraz argumentu, że nie chce obciążać porządnych ludzi - Polaków, którzy jej pomogli, przekonała szantażystów do odejścia. Obawa przed ponownym najściem skłoniła je do ucieczki do Warszawy, na znany im Żoliborz, gdzie zamieszkały w wynajętym pokoju przy ul. Wyspiańskiego. Działo się to krótko przed likwidacją falenickiego getta w sierpniu 1942 r. Niebawem przeżyły ponowne najście szantażystów, którzy zażądali wysokiego okupu pod groźbą donosu na Gestapo. Idalia wykupiła życie dzięki pożyczce od znajomej, dr Poczętowskiej, udostępniającej jej swój gabinet, by mogła przyjmować zaufanych pacjentów. Nie oznaczało to końca kłopotów - Danuta wspominała, że pewnego razu ktoś zawołał na nią na ulicy „Żydówa”. W obawie o jej życie matka zdecydowała się umieścić córkę w sierocińcu działającym pod auspicjami Rady Głównej Opiekuńczej, a następnie, gdy jej zasugerowano, że dziewczynka nie może tam dłużej przebywać, przeniosła Danutę do klasztoru Sióstr Serca Maryi przy ul. Kilińskiego na Starym Mieście ${ }^{8}$. Tam też przeżyła powstanie warszawskie. Po zakończeniu walk Danuta została wywieziona wraz z sierocińcem i siostrami zakonnymi do Niemiec do pracy przymusowej. Doczekała tam wyzwolenia9

Po zakończeniu wojny w maju 1945 r. wróciła do Polski i zamieszkała z matką w Końskich, skąd we wrześniu przeniosły się do Warszawy. Jeszcze w tym samym roku Danuta zdała egzamin dojrzałości, a następnie rozpoczęła studia w Szkole Głównej Handlowej ${ }^{10}$. W listopadzie 1946 r. została przyjęta na Wydział Humanistyczny Uniwersytetu Warszawskiego, gdzie podjęła studia na kierunkach romanistyka i anglistyka. W marcu 1953 r. otrzymała dyplom magistra filozofii w zakresie filologii francuskiej, temat rozprawy magisterskiej brzmiał „Le probleme de l'authentucute du Cinquieme Livre de Rabelais”"11. Jeszcze na studiach zaangażowała się w działalność Zjednoczonej Żydowskiej Partii Robotniczej Poalej Syjon-Lewica - Ha-Szomer Ha-Cair, której była członkiem od lutego do grudnia $1949 \mathrm{r}^{12}$

Od października 1949 do maja 1951 r. pracowała w bibliotece Głównego Instytutu Chemii Przemysłowej, gdzie była odpowiedzialna za gromadzenie zbio-

\footnotetext{
${ }^{8}$ Ibidem.

${ }^{9}$ Ibidem; AŻıH, Akta personalne, t. 6, Dąbrowska Danuta - Życiorys, k. 32.

${ }^{10}$ Ibidem.

${ }^{11}$ AUW, Akta studenta Dąbrowska Danuta, dyplom nr 238, b.p.; ibidem, Protokół egzami-

${ }^{12}$ AŻ̇H, Akta personalne, t. 6, Kwestionariusz osobowy, k. 37.
} nu, b.p. 
rów, w tym zakupy publikacji zagranicznych i prenumeraty, następnie zaś przy sporządzaniu katalogu biblioteki. W opinii kierownictwa „pracowała sumiennie i inteligentnie. Wykazywała duże zdolności w poznawaniu nowych dla niej dziedzin pracy, jak i w opanowywaniu języków"13. Praca w bibliotece okazała się dobrym przygotowaniem do kolejnego wyzwania, jakim była praca w Żydowskim Instytucie Historycznym w Warszawie, którą podjęła już w czerwcu 1951 r., godząc ją ze studiami wyższymi ${ }^{14}$. W ŻIH pracowała początkowo na stanowisku tłumacza-korektora, następnie archiwisty. Odręczne adnotacje na dokumentach archiwalnych wskazują, że pracowała przy porządkowaniu wielkiej spuścizny getta łódzkiego znajdującej się wówczas w zbiorach Ż̇H ${ }^{15}$. Później była zatrudniona na stanowisku pracownika naukowo-technicznego związanego z Biblioteką Instytutu. Jednocześnie włączyła się w prace przy redakcji „Biuletynu Żydowskiego Instytutu Historycznego" jako tłumacz i redaktor tekstów obcojęzycznych. W opinii przełożonego Artura Eisenbacha Dąbrowska odznaczała się „sumiennością, dokładnością oraz koleżeńskim stosunkiem do pracowników, którym udziela wydatnej pomocy w ramach swych umiejętności"16.

Pierwsza praca naukowa Danuty Dąbrowskiej dotyczyła zagłady lokalnych społeczności w Kraju Warty (temat, który po dziś dzień nie doczekał się kontynuatora). Artykuł temu poświęcony został opublikowany w numerze 13/14 „Biuletynu ŻIH” z $1955 \mathrm{r}^{17}$ W kolejnych pracach badaczka skupiła się na dziejach łódzkiej „dzielnicy zamkniętej”, którym poświęciła kilka tekstów publikowanych nadal na łamach „Biuletynu ŻIH”. W 1961 r. podjęła niezwykle ciekawy temat podań - pomysłów racjonalizatorskich w organizacji getta, kierowanych do Przełożonego Starszeństwa Żydów przez więźniów getta ${ }^{18}$, a dwa lata później opisała początki tworzenia się struktur administracji żydowskiej kierowanej przez Mordechaja Chaima Rumkowskiego. Rezultatem badań nad administracją getta były dwa obszerne artykuły opublikowane w „Biuletynie ŻıH”19. Wspomniane artykuły towarzyszyły pracom nad pełną naukową edycją „Biuletynu Kroniki Codziennej” zwaną Kronika getta łódzkiego, którą realizowała wraz z Lucjanem Dobroszyckim, historykiem związanym wówczas z Polską Akademią Nauk, oca-

\footnotetext{
${ }^{13}$ APIN, 0423/9390, Opinia, k. 12.

${ }^{14}$ AŻIH, Akta personalne, t. 6, Dąbrowska Danuta, k. 25.

${ }^{15}$ Zob. np. notatki na marginesach na kilku stronach w Archiwum Państwowym w Łodzi, zespół Przełożony Starszeństwa Żydów, 1089.

${ }^{16}$ AŻIH, Akta personalne, t. 6, Danuta Dąbrowska, Opinia, k. 15.

${ }^{17}$ Zagłada skupisk żydowskich $w$ „Kraju Warty” w okresie okupacji hitlerowskiej, „Biuletyn ŻIH” 1955, nr 1/2 (13/14), s. 122-184.

${ }^{18}$ O projektach poprawy sytuacji ludności w getcie łódzkim (wnioski mieszkańców getta z lat 1940-1942), „Biuletyn ŻIH” 1961, nr 2 (38), s. 118-127.

${ }^{19}$ Administracja żydowska $w$ Łodzi i jej agendy w okresie od początku okupacji do zamknięcia getta...; Struktura i funkcje administracji żydowskiej getta łódzkiego (maj-grudzień 1940 r.), cz. 1, „Biuletyn ŻIH” 1964, nr 3 (51), s. 41-57; Struktura i funkcje administracji żydowskiej w getcie łódzkim (maj-grudzień 1940 r.), cz. 2, „Biuletyn ŻIH” 1964, nr 4 (52), s. 35-48.
} 
leńcem z getta łódzkiego. Prace nad edycją tego wyjątkowego dla dziejów getta źródła rozpoczęto w kwietniu 1963 r. Zdaniem Jacka Walickiego Dobroszycki był liderem zespołu, a Dąbrowska odpowiadała za żmudną pracę edytorską i tłumaczenia, co mają potwierdzać podpisy złożone pod poszczególnymi częściami wstępu - wprowadzenie historyczne podpisane przez Dobroszyckiego oraz nota edytorska podpisana przez Dąbrowską ${ }^{20}$. W umowie wydawniczej deklarowano przygotowanie trzech tomów w terminie do końca 1964 r. $^{21}$ Zanim nakładem Wydawnictwa Łódzkiego ukazał się pierwszy tom Kroniki, w 1963 r. w „Głosie Robotniczym" opublikowano najbardziej wstrząsające fragmenty poświęcone deportacji z września 1942 r., tzw. wielkiej szperze ${ }^{22}$. Prace nad wydaniem Kroniki początkowo przebiegały zgodnie z planem - w 1965 r. ukazał się pierwszy tom, obejmujący okres od stycznia 1941 do maja $1942 \mathrm{r}^{23}$, rok później na rynku dostępny był kolejny, obejmujący okres od czerwca do grudnia $1942 \mathrm{r}^{24}$ Dalsze prace nad wydaniem Kroniki splątały się z wydarzeniami politycznymi w Polsce - wybuchem kampanii antysemickiej po przemówieniu Władysława Gomułki na VI Kongresie Związków Zawodowych. Jej efektem była inwigilacja działalności Wydawnictwa Łódzkiego i ostra krytyka jego produkcji wydawniczej. Aktywność Dobroszyckiego, jego kontakty z ambasadą Izraela i mieszkającym w Szwecji Nachmanem Zonabendem, który przyczynił się do ocalenia części spuścizny archiwalnej z getta, skupiała uwagę Służby Bezpieczeństwa ${ }^{25}$. Mimo to prace redakcyjne nad wydaniem Kroniki nie ustały - do wydawnictwa dostarczono trzeci i czwarty tom. Ostatecznie w październiku 1968 r. Wydawnictwo Łódzkie odstąpiło od wydania dwóch ostatnich tomów, a jego dyrektor uzasadnił to zdaniem: „Kronika getta łódzkiego jako dokument oderwany od kontekstu wydarzeń okupacyjnych nie nadaje się do wydania w formie książkowej"26. Gdy dyrektor wydawnictwa sporządzał notatkę, Dąbrowskiej nie było już w kraju wyjechała z Polski do Izraela we wrześniu 1968 r. ${ }^{27}$ Sprawa zaniechania prac

${ }^{20}$ Zwrócił na to uwagę Jacek Walicki w opracowaniu poświęconym wydaniu Kroniki (idem, Polityka historyczna a nauka. Dzieje badań materiałów archiwalnych getta łódzkiego i jego Kroniki do roku 1968 [w:] Kronika getta łódzkiego / Litzmannstadt Getto 1941-1944, t. 5: Suplementy, red. Julian Baranowski i in., Łódź: Wydawnictwo UŁ i Archiwum Państwowe w Łodzi, 2009, s. 261.

${ }^{21}$ AIPN, 0423/9390, Umowa wydawnicza, k. 4.

22 „Szpera” - fragment oficjalnej kroniki getta, „Głos Robotniczy” 1963, nr 248, s. 4; „Szpera” - fragment oficjalnej kroniki getta, „Głos Robotniczy” 1963, nr 254, s. 4.

${ }^{23}$ Kronika getta łódzkiego, t. 1: Styczeń 1941 - maj 1942, z oryg. do druku przygotowali, wstępem i przypisami zaopatrzyli Danuta Dąbrowska, Lucjan Dobroszycki, Łódź: Wydawnictwo Łódzkie, 1965.

${ }^{24}$ Kronika getta łódzkiego, t. 2: Czerwiec - grudzień 1942, z oryg. do druku przygotowali, wstępem i przypisami zaopatrzyli Danuta Dąbrowska, Lucjan Dobroszycki, Łódź: Wydawnictwo Łódzkie, 1966.

${ }^{25}$ Walicki, Polityka historyczna a nauka..., s. 261.

${ }^{26}$ Więcej o kulisach wydania Kroniki zob. ibidem, s. 260-267.

${ }^{27}$ Zanim ostatecznie wyjechała z Polski, dwukrotnie uzyskała zgodę na wyjazd - w 1957 i 1959 r., przy drugiej rezygnacji naczelnik Wydziału III Biura Paszportów Zagranicznych 
nad wydaniem Kroniki odcisnęła piętno na badaczce, która poproszona o przyjazd do Polski z okazji premiery pełnego wydania Kroniki w 2009 r., przyznała: „dziś są inne rzeczy i inni ludzie, ale niechęć pozostaje”28. Przed opuszczeniem Polski zdążyła opublikować wyniki prac nad losem Żydów z Rzeszy i Protektoratu deportowanych jesienią 1941 r. do łódzkiego getta ${ }^{29}$.

Równolegle z pracami naukowymi Dąbrowska widnieje jako tłumaczka w kilku ważnych edycjach źródłowych, w tym fundamentalnej pracy Eksterminacja Żydów na ziemiach polskich w okresie okupacji hitlerowskiej z $1957 \mathrm{r}^{30}$, raportu Jürgena Stroopa ${ }^{31}$ oraz fragmentów dziennika Hansa Franka ${ }^{32}$. Jako tłumaczka dokumentów z języka żydowskiego i polskiego na niemiecki pracowała przy wydanym w Niemczech zbiorze Faschismus, Getto, Massenmord ${ }^{33}$.

W Izraelu rozpoczęła pracę w Instytucie Yad Vashem, gdzie nadal łączyła wybitne zdolności translatorskie z warsztatem historyka. Znalazła się w zespole historyków przygotowujących tom Encyklopedii gmin żydowskich w Polsce (Pinkas ha-kehilot Polin) poświęcony Łodzi i regionowi łódzkiemu - wydany w $1976 \mathrm{r}^{34}$ Kilka lat wcześniej przygotowała cenną bibliografię tekstów dotyczących Żydów wschodnioeuropejskich pojawiających się w zachodnich periodykach naukowych ${ }^{35}$. Poza Pinkasem łódzkie tematy były nieobecne w pracach

MSW odręcznie zapisał: „Przy następnym podaniu o wyjazd proponuję załatwiać nie mniej jak 2 lata. W 1957 r. otrzymała zgodę - zrezygnowała. Obecnie - po wszystkich sprawdzaniach zagwarantowaniu [?] sprawy też rezygnuje. Zakrawa to na kpiny" (AIPN, 1268/20326, t. 2, Notatka, k. 25; ibidem, Wniosek paszportowy, k. 34).

${ }^{28}$ Zbiory Centrum Badań Żydowskich UŁ, List Danuty Dąbrowskiej do Ewy Wiatr, 16 VIII $2009 \mathrm{r}$.

${ }^{29}$ Wsiedleni Żydzi zachodnioeuropejscy w getcie łódzkim, „Biuletyn ŻIH” 1968, nr 1/2 (65/66), s. 105-139.

${ }^{30}$ Eksterminacja Żydów na ziemiach polskich $w$ okresie okupacji hitlerowskiej. Zbiór dokumentów, zebrali i opracowali Tatiana Berenstein, Artur Eisenbach, Adam Rutkowski, [dokumenty niemieckie tłum. Danuta Dąbrowska], Warszawa: ŻIH, 1957.

${ }^{31}$ The Report of Jürgen Stroop concerning the uprising in the Ghetto of Warsaw and the liquidation of the Jewish residential area, przedmowa i przypisy Bernard Mark, tłum. Danuta Dąbrowska, Warszawa: Stowarzyszenie Żydowski Instytut Historyczny w Polsce, 1958.

${ }^{32}$ Okupacja i ruch oporu w Dzienniku Hansa Franka 1939-1945, t. 2: 1943-1945, wyboru dokonali pod nauk. kierownictwem Stanisława Płoskiego Lucjan Dobroszycki i in., tłum. Danuta Dąbrowska, Mieczysław Tomala, Warszawa: Książka i Wiedza, 1972.

${ }^{33}$ Faschismus, Getto, Massenmord. Dokumentation über Ausrottung und Widerstand der Juden in Polen während des Zweiten Weltkrieges, red. Tatiana Berenstein i in., przedmowa Siegfried Einstein, tłum. na język niemiecki dokumentów w językach polskim i jidysz Danuta, Frankfurt am Main: Röderberg-Verlag, 1962.

${ }^{34}$ Pinkas ha-kehilot Polin. Enciklopedia szel ha-jiszuwim ha-Jehudim le-min hiwasdam we-ad le-ahar Szoat milchemet ha-olam ha szenija, red. Danuta Dabrowska, Abraham Wein, autorzy: Pesach Egoldberg, Danuta Dabrowska, Abraham Wein Jakubowicz, Aharon Weiss, Jerusalem: Yad Vashem, 1976.

${ }^{35}$ Soviet and East European Jewry as Reflected in Western Periodicals: an annotated bibliography, wybór Danuta Dombrovska, oprac. Benjamin Pinkus, Jerusalem: Hebrew University, 
historyczki, która skupiła się na aktywności w archiwum, gdzie pracowała do emerytury. Mimo zachęty nie przyjęła propozycji, by napisać rozprawę doktorską $\mathrm{w}$ ramach pracy $\mathrm{w}$ Yad Vashem ${ }^{36}$. W latach dziewięćdziesiątych nadal podejmowała się prac translatorskich - $w$ jej tłumaczeniu na język angielski ukazały się Stosunki polsko-żydowskie Emanuela Ringelbluma ${ }^{37}$, a także niemieckie wydanie wspomnień Noacha Lasmana, przełożone przez nią z hebrajskiego $^{38}$.

Dąbrowska, jak sama pisała, na wiele lat „wzięła rozbrat z tematyką Holokaustu”, jedyny „ostatni” wyjątek, jaki uczyniła, to podjęcie się w 2008 r. sprawdzenia niemieckiej edycji Kroniki getta łódzkiego, przygotowywanej przez Uniwersytet w Giessen we współpracy z Uniwersytetem Łódzkim. Ów wyjątek motywowany był przekonaniem o dużej wartości naukowej projektu oraz „sumienności i uczciwości tej publikacji”39. Jak się później miało okazać, była to ostatnia aktywność naukowa Danuty Dąbrowskiej. W 2013 r. wystąpiła jeszcze w dokumencie Joanny Król i Karoliny Dzięciołowskiej Ocaleni, gdzie można było w pełni dostrzec jej ciepło i wyjątkowe poczucie humoru. Zmarła w Giwatajim w Izraelu 17 kwietnia 2015 r. w wieku 90 lat.

\section{BIBLIOGRAFIA}

\section{Publikacje autorskie Danuty Dabrowskiej}

Administracja żydowska $w$ Łodzi i jej agendy $w$ okresie od poczq̨tku okupacji do zamknięcia getta (8 IX 1939 - 30 IV 1940), „Biuletyn ŻIH” 1963, nr 1/2 (45/46).

Zagłada skupisk żydowskich w „Kraju Warty” w okresie okupacji hitlerowskiej, „Biuletyn ŻIH" 1955, nr 1/2 (13/14).

o projektach poprawy sytuacji ludności w getcie łódzkim (wnioski mieszkańców getta z lat 1940-1942), „Biuletyn ŻıH” 1961, nr 2 (38).

Struktura i funkcje administracji żydowskiej getta łódzkiego (maj-grudzień 1940 r.), cz. 1, „Biuletyn ŻIH” 1964, nr 3 (51).

Struktura i funkcje administracji żydowskiej w getcie łódzkim (maj-grudzień 1940 r.), cz. 2, „Biuletyn ŻıH” 1964, nr 4 (52).

Wsiedleni Żydzi zachodnioeuropejscy w getcie łódzkim, „Biuletyn ŻIH” 1968, nr 1/2 (65/66).

Center for Documentation of East European Jewry, Society for Research on Jewish Communities, 1972.

${ }^{36}$ Zbiory Centrum Badań Żydowskich UŁ, List Danuty Dąbrowskiej do Ewy Wiatr, 16 VIII $2009 \mathrm{r}$.

${ }^{37}$ Emmanuel Ringelblum, Polish-Jewish Relations during the Second World War, oprac. Joseph Kermish, Shmuel Krakowski, tłum. z języka polskiego Dafna Allon, Danuta Dabrowska, Dana Keren, Evanston: Northwestern University Press, 1992.

${ }^{38}$ Noah Lasman, Die Straße. Erinnerungen eines jüdischen Zwangsarbeiters an eine „ganz normale Firma”, tłum. z języka hebrajskiego Danuta Dombrowska, Münster: Waxmann, 1999.

${ }^{39}$ Zbiory Centrum Badań Żydowskich UŁ, List Danuty Dąbrowskiej do Ewy Wiatr, 16 VIII 2009 r. 


\section{Publikacje w opracowaniu Danuty Dąbrowskiej}

Kronika getta łódzkiego, t. 1: Styczeń 1941 - maj 1942, z oryg. do druku przygotowali, wstępem i przypisami zaopatrzyli Danuta Dąbrowska, Lucjan Dobroszycki, Łódź: Wydawnictwo Łódzkie, 1965.

Kronika getta łódzkiego, t. 2: Czerwiec-grudzień 1942, z oryg. do druku przygotowali, wstępem i przypisami zaopatrzyli Danuta Dąbrowska, Lucjan Dobroszycki, Łódź: Wydawnictwo Łódzkie, 1966.

Pinkas ha-kehilot Polin. Enciklopedia szel ha-jiszuwim ha-Jehudim le-min hiwasdam wead le-ahar Szoat milchemet ha-olam ha szenija, red. Danuta Dabrowska, Abraham Wein, autorzy: Pesach Egoldberg, Danuta Dabrowska, Abraham Wein Jakubowicz, Aharon Weiss, Jerusalem: Yad Vashem, 1976.

„Szpera” - fragment oficjalnej kroniki getta, „Głos Robotniczy” 1963, nr 248.

„Szpera” - fragment oficjalnej kroniki getta, „Głos Robotniczy” 1963, nr 254.

Soviet and East European Jewry as Reflected in Western Periodicals: an annotated bibliography, wybór Danuta Dombrovska, oprac. Benjamin Pinkus, Jerusalem: Hebrew University, Center for Documentation of East European Jewry, Society for Research on Jewish Communities, 1972.

\section{Publikacje zawierające przekłady Danuty Dąbrowskiej}

Eksterminacja Żydów na ziemiach polskich w okresie okupacji hitlerowskiej. Zbiór dokumentów, zebrali i opracowali Tatiana Berenstein, Artur Eisenbach, Adam Rutkowski, [dokumenty niemieckie tłum. Danuta Dąbrowska], Warszawa: ŻIH, 1957.

Faschismus, Getto, Massenmord. Dokumentation über Ausrottung und Widerstand der Juden in Polen während des Zweiten Weltkrieges, red. Tatiana Berenstein i in., przedmowa Siegfried Einstein, tłum. na język niemiecki dokumentów w językach polskim i jidysz Danuta, Frankfurt am Main: Röderberg-Verlag, 1962.

Lasman Noah, Die Straße. Erinnerungen eines jüdischen Zwangsarbeiters an eine „ganz normale Firma", tłum. z języka hebrajskiego Danuta Dombrowska, Münster: Waxmann, 1999.

Okupacja i ruch oporu w Dzienniku Hansa Franka 1939-1945, t. 2: 1943-1945, wyboru dokonali pod nauk. kierownictwem Stanisława Płoskiego Lucjan Dobroszycki i in., tłum. Danuta Dąbrowska, Mieczysław Tomala, Warszawa: Książka i Wiedza, 1972.

The Report of Jürgen Stroop concerning the uprising in the Ghetto of Warsaw and the liquidation of the Jewish residential area, przedmowa i przypisy Bernard Mark, tłum. Danuta Dąbrowska, Warszawa: Stowarzyszenie Żydowski Instytut Historyczny w Polsce, 1958.

Ringelblum Emmanuel, Polish-Jewish Relations during the Second World War, oprac. Joseph Kermish, Shmuel Krakowski, tłum. z języka polskiego Dafna Allon, Danuta Dabrowska, Dana Keren, Evanston: Northwestern University Press, 1992.

\section{Źródła archiwalne}

Archiwum Instytutu Pamięci Narodowej (AIPN) 0423/9390, 1268/20326, t. 2

Archiwum Państwowe $w$ Lodzi Przełożony Starszeństwa Żydów, 1089

Archiwum Uniwersytetu Warszawskiego (AUW)

Akta studenta Dąbrowska Danuta

Archiwum Żydowskiego Instytutu Historycznego (AŻıH)

Akta personalne, t. 6, Dąbrowska Danuta 


\section{Zbiory Centrum Badań Żydowskich Uniwersytetu Łódzkiego}

List Danuty Dąbrowskiej do Ewy Wiatr, 16 VIII 2009 r.

\section{Opracowania}

Sitarek Adam, „Otoczone drutem państwo”. Struktura i funkcjonowanie administracji żydowskiej getta łódzkiego, Łódź: IPN, 2016.

Walicki Jacek, Polityka historyczna a nauka. Dzieje badań materiałów archiwalnych getta łódzkiego i jego Kroniki do roku 1968 [w:] Kronika getta łódzkiego / Litzmannstadt Getto 1941-1944, t. 5: Suplementy, red. Julian Baranowski i in., Łódź: Wydawnictwo UŁ i Archiwum Państwowe w Łodzi, 2009.

\section{Netografia}

Jakoba Blidsztejn (Danuta Dąbrowska) - Ocalona, https://sprawiedliwi.org.pl/pl/historie-pomocy/wasze-opowiesci/jakoba-blidsztejn-danuta-dabrowska-ocalona

\section{Filmografia}

Ocaleni, 2013, reż. Joanna Król, Karolina Dzięciołowska, realizacja Muzeum Historii Żydów Polskich Polin 